\title{
Penggunaan internet sebagai sumber informasi dalam penyusunan karya ilmiah siswa SMA Negeri 8 Yogyakarta
}

\author{
Ezra Putranda Setiawan', Ismurjanti ${ }^{2}$ \\ 1,2 SMA Negeri 8 Yogyakarta \\ Jl. Sidobali 1, Muja-Muju, Umbulharjo, Yogyakarta 55165 \\ E-mail: ${ }^{1}$ ezra.putranda.s@mail.ugm.ac.id, 2ismurjanti@gmail.com
}

Received: September 2018; Accepted: December 2018; Published: December 2018

\begin{abstract}
Currently, the internet is one of the essential and user-friendly sources of information, even by students at the school. On the other hand, internet users also run the risk of obtaining inaccurate information or hoaxes. This study aimed to determine the behavior of using the internet as a source of information by Senior High School students (SMA), considering high school students began to be exposed to the internet when writing simple research reports. The research method used was documentation with a quantitative approach, namely by observing some written works of students from grade X (first year) of the State Senior High School 8 Yogyakarta in the 2016/2017 and 2017/2018 school year. The student's essay consists of three disciplines, namely biological science, engineering, and technology, as well as social science and humanities. The study focused on sources of information from the internet used in the scientific papers. Each paper's list of reference was analyzed by grouping internet citations. Results showed that from 166 sample papers, the internet dominated the reference sources listed in the bibliography, with a percentage of around $60 \%$. The types of internet sites that were widely cited by students were blogs, repositories, and general websites. More than $95 \%$ of sites used were in the Indonesian language. In conclusion, senior high school students need further assistance in accessing the internet, primarily to identify valid sources of information and avoid dubious information sources.
\end{abstract}

Keywords: Citation analysis; Scientific paper; Senior high school; Student

\begin{abstract}
Abstrak
Dewasa ini, internet merupakan salah satu sumber informasi yang penting dan mudah digunakan, tidak terkecuali oleh para pelajar di sekolah. Di sisi lain, pengguna internet juga menghadapi risiko adanya informasi yang tidak akurat atau hoax. Penelitian ini bertujuan untuk mengetahui perilaku penggunaan internet sebagai sumber informasi oleh pelajar jenjang Sekolah Menengah Atas (SMA), mengingat siswa SMA sudah mulai terpapar dengan penulisan laporan penelitian sederhana. Penelitian dilakukan dengan metode dokumentasi dengan pendekatan kuantitatif, yakni dengan mengamati sejumlah karya tulis siswa Sekolah Menengah Atas (SMA) Negeri 8 Yogyakarta kelas X pada tahun ajaran 2016/2017 dan 2017/2018. Karya tulis siswa tersebut terdiri dari tiga bidang ilmu, yakni sains hayati, rekayasa dan teknik, serta sosial dan humaniora. Analisis dilakukan pada daftar pustaka masing-masing karya tulis tersebut. Penelitian difokuskan pada sumber informasi dari internet yang digunakan dalam karya-karya tulis ilmiah tersebut. Berdasarkan observasi terhadap 166 sampel karya tulis ilmiah, diketahui bahwa internet mendominasi sumber referensi yang tercantum dalam daftar pustaka, dengan persentase sekitar $60 \%$. Jenis situs internet yang banyak dikutip oleh siswa adalah blog, repositori, dan situs umum. Lebih dari $95 \%$ situs yang digunakan berbahasa Indonesia, sedangkan sisanya berbahasa asing. Simpulan penelitian ini, diperlukan pendampingan lebih lanjut pada siswa SMA dalam mengakses internet, khususnya untuk mengidentifikasi sumber-sumber informasi yang valid serta menghindari informasi yang diragukan kebenarannya.
\end{abstract}

Kata Kunci: Analisis sitiran; Karya tulis ilmiah; Sekolah menengah atas; Pelajar 


\section{PENDAHULUAN}

Salah satu penemuan terbesar abad ke-20 adalah interconnected network atau lebih dikenal sebagai internet. Teknologi ini lahir dari keperluan adanya metode komunikasi antar komputer di Amerika Serikat untuk keperluan pertahanan pada masa Perang Dingin. Kemajuan internet semakin pesat ketika ditemukan world wide web (www), yang dapat dibuat di seluruh dunia dan digunakan untuk menyediakan informasi-informasi tertentu baik berupa dokumen maupun tautan. Fasilitas web terus berkembang hingga muncul Web 2.0 yang memungkinkan pengguna web mengubah halaman web yang telah dibuat orang lain, menerima pesan singkat (notifikasi), dan sebagainya. Versi terbaru web saat ini dikenal sebagai Web 3.0, yang memungkinkan halaman web membaca informasi dari halaman lain, merekam riwayat penggunaan halaman web, dan meningkatkan kemampuan internet dalam menyediakan informasi sesuai kebutuhan pengguna (Prasetiadi, 2011).

Penemuan internet membawa perubahan besar dalam berbagai bidang kehidupan, khususnya terkait pencarian informasi, penyebaran informasi, hingga komunikasi sehari-hari antar masyarakat secara umum. Dalam hal pencarian informasi, internet membantu masyarakat untuk memperoleh informasi dari berbagai sumber dalam waktu yang singkat. Internet dapat dipandang sebagai suatu perpustakaan raksasa (Handayani, 2012). Dalam hal pengiriman informasi dan komunikasi, internet memungkinkan dilakukannya komunikasi dari berbagai daerah bahkan berbagai negara dengan biaya yang sangat rendah, yakni dengan surel (e-mail), media sosial (social media), dan aplikasi lain, misalnya WhattsApp (WA). Internet juga menjadi sarana untuk melakukan aktivitas perdagangan barang dan jasa, misalnya dengan bantuan situs jual beli (misal tokopedia.com, bukalapak.com, dan lain-lain) atau hanya sekedar memasang iklan. Seseorang yang menggunakan internet dapat juga mengakses layanan perbankan, perpajakan, dan lain sebagainya.

Berdasarkan survei tahunan Asosiasi Penyelenggara Jasa Internet Indonesia APJII (2017), pada tahun 2017, sebanyak $75,5 \%$ dari penduduk Indonesia yang berusia 13-18 tahun merupakan pengguna internet. Selain itu, sebanyak 65,98\% pengguna internet akan terhubung dengan internet setiap hari, dengan durasi terbanyak antara 1-3 jam (43,89\%). Penelusuran informasi dengan mesin pencari (search engine) dilakukan sebanyak 74,84\% pengguna layanan internet, terletak di tempat ketiga setelah layanan chatting dan penggunaan media sosial (data lengkap tersedia di situs apjii.or.id). Hal ini menandakan bahwa tidak sedikit remaja usia sekolah di Indonesia yang menggunakan internet dalam kehidupan sehari-hari.

Bagi kalangan pelajar, salah satu fungsi terpenting internet adalah untuk melakukan pencarian informasi. Informasi yang diperoleh dari internet dapat digunakan untuk berbagai keperluan, misalnya mengerjakan tugas-tugas dari sekolah, memperdalam pengetahuan tentang berbagai topik, mengembangkan keterampilan atau bakat tertentu, dan lain sebagainya. Fungsi berikutnya yang tidak kalah penting adalah fungsi komunikasi dan hiburan, yang memungkinkan pelajar melakukan diskusi, berbagi cerita, hingga mengisi waktu luang. Internet juga dapat digunakan dalam proses belajar-mengajar di sekolah, dan sejauh ini memberikan hasil yang memuaskan (Wardhani, 2013; 
Supardi \& Putri, 2010; Imron, Palekahelu, \& Somya, 2014; Rahardiyan, 2013).

Pencarian informasi di internet memiliki beberapa keunggulan. Pertama, internet dapat diakses dari berbagai lokasi sehingga pencarian informasi dapat dilakukan dari mana saja, baik dari rumah, sekolah, kafe, perpustakaan, maupun tempat-tempat lainnya. Kedua, informasi dapat diperoleh dengan cepat, mengingat saat ini telah tersedia berbagai situs mesin pencari (search engine), misalnya Google, Yahoo, dan lain sebagainya. Mesin-mesin pencari ini dapat menemukan berbagai informasi di internet sehingga pengguna atau pencari informasi tidak perlu mengetahui lokasi penempatan informasi terebut. Ketiga, informasi di internet tersedia setiap saat, sehingga pencarian tidak lagi dibatasi oleh waktu seperti pada pencarian informasi manual. Dari segi biaya, internet menyediakan banyak informasi secara gratis sehingga pengguna hanya perlu mengeluarkan biaya untuk terhubung dengan layanan internet. Biaya ini pun seringkali tidak perlu dikeluarkan oleh pengguna karena tersedia akses internet gratis di berbagai tempat umum, baik di sekolah, kafe, maupun tempattempat lainnya. Pencarian informasi di internet juga didukung dengan meningkatnya kualitas jaringan internet, terutama di kawasan perkotaan.

Melihat uraian di atas, masuk akal bila penggunaan internet sebagai sumber referensi mengalami peningkatan. Cooke and Rosenthal (2011), menyebutkan bahwa hampir $65 \%$ dari keseluruhan referensi yang digunakan dalam penyusunan tugas mahasiswa diperoleh dari internet. Sin and Kim (2013) menunjukkan bahwa situs jejaring sosial (social networking sites) banyak digunakan untuk pencarian informasi sehari-hari, terutama oleh orang-orang muda dan para mahasiswa.

Di sisi lain, pencarian informasi di internet juga mengandung kelemahan besar, yakni tidak adanya kepastian bahwa seluruh informasi yang tersedia di internet adalah benar dan tepat. Tidak jarang di internet dijumpai kabar-kabar hoax, atau kabar-kabar yang tidak benar. Survey yang dilakukan oleh Masyarakat Telematika Indonesia, menunjukkan bahwa sebanyak $44,3 \%$ pengguna internet menerima kabar hoax setiap hari, bahkan sebanyak 17,2\% menerima kabar hoax lebih dari sekali dalam satu hari (Suara Sektor ICT Indonesia, 2017).

Informasi-informasi hoax ini dapat menimbulkan berbagai masalah. Suatu kalimat yang seakan-akan berupa fakta, ternyata hanya kalimat propaganda yang diciptakan untuk menarik perhatian atau dukungan orang lain. Sebagai contoh, klaim tentang khasiat atau kegunaan obatobat yang tersedia di internet tidak jarang disusun untuk menarik minat para pembeli obat tanpa didukung oleh penelitian yang valid. Beberapa berita hoax bahkan sengaja dibuat untuk menjatuhkan pihak-pihak tertentu.

Adanya informasi hoax atau infor-masi yang tidak benar menimbulkan perbedaan tingkat kepercayaan terhadap berbagai macam situs internet. Keyakinan terhadap pernyataan yang dikeluarkan oleh situs resmi suatu lembaga negara tentu tidak sama dengan pernyataan yang dikeluarkan seseorang dengan identitas tidak jelas di blog atau situs pribadinya. Yale University (2018), menceritakan bahwa,

"In the context of writing in college, material from much of the Internet is less reliable than print sources because it's hard to tell who wrote or posted it". 
Dengan kata lain, tidak selalu dapat dipas-tikan siapa yang mempublikasikan suatu informasi di internet, atau siapa yang ber-tanggungjawab atas kebenaran suatu informasi di internet. Bahkan bila situs tersebut mencantumkan nama penulis, belum diketahui apakah tulisan itu meru-pakan tulisan asli atau kutipan dari sumber lain. Bila merupakan tulisan asli, belum diketahui apakah sang penulis memiliki kompetensi atau kelayakan untuk membuat pernyataan tersebut.

Uraian di atas menunjukkan bahwa tidak semua informasi di internet dapat diuji kebenarannya, atau digunakan sebagai dasar dalam penulisan ilmiah. Penggunaan informasi yang salah sebagai rujukan menyebabkan kualitas suatu karya ilmiah tidak dapat dipertanggungjawabkan.

Di kalangan perguruan tinggi, penggunaan internet sebagai sumber referensi telah diungkap dalam beberapa penelitian. Zahra (2009), Suharni (2012), dan Lestari (2015), menyatakan bahwa niat mahasiswa menggunakan internet sebagai sumber informasi dipengaruhi oleh tiga variabel, yakni kualitas informasi, norma subjektif, dan kemampuan individual. Kim and Sin (2011) menunjukkan bahwa pilihan sumber referensi mahasiswa berturut-turut adalah mesin pencari (search engine), situs web, basis data dan jurnal daring (online), buku tercetak dan katalog internet. Terdapat beberapa kriteria pemilihan sumber referensi, yakni keakuratan (kepercayaan), aksesibilitas, kemudahan dalam menggunakan, biaya (gratis), serta kebaruan informasi yang tersedia. Senada dengan hasil tersebut, Purdy (2012) menyebutkan bahwa sumber yang banyak digunakan oleh para mahasiswa adalah mesin pencari umum, diikuti dengan mesin pencari karya tulis ilmiah (scholarly search engines), basis data jurnal daring, diikuti dengan buku. Selwyn (2008) menunjukkan bahwa perilaku pencarian informasi di internet oleh mahasiswa dipengaruhi oleh beberapa faktor, yakni keluasan akses, lama studi, jenis kelamin, usia, etnis, dan pendidikan sebelumnya. Joo and Choi (2015), menyatakan bahwa penggunaan internet sebagai sumber informasi didukung oleh beberapa faktor yang meliputi kemudahan akses, kemanfaatan, aksesibilitas, kredibilitas, kelengkapan/jangkauan, biaya, dan format.

Banyaknya riset mengenai penggunaan internet sebagai sumber referensi di kalangan mahasiswa ternyata belum diikuti oleh riset di jenjang yang lebih rendah, yakni pelajar sekolah menengah. Padahal, pelajar jenjang Sekolah Menengah Atas (SMA) telah mengenal karya tulis ilmiah dan laporan penelitian, mengingat keduanya merupakan kompetensi pelajaran di jenjang tersebut. Sebagai contoh, salah satu kompetensi dasar mata pelajaran bahasa Indonesia (wajib) kelas XI SMA sesuai kurikulum 2013 revisi 2016 adalah merancang sebuah proposal karya ilmiah dengan memerhatikan informasi, tujuan, dan esensi karya ilmiah yang diperlukan. Pada mata pelajaran Sejarah Indonesia (wajib) kelas XII SMA kurikulum yang sama, peserta didik dituntut untuk dapat melakukan penelitian sederhana tentang kehidupan politik dan ekonomi bangsa Indonesia pada masa Demokrasi Terpimpin, masa Orde Baru, dan masa awal reformasi serta menyajikannya dalam laporan tertulis.

Kompetensi dasar terkait dengan penelitian siswa juga dapat dijumpai dalam beberapa mata pelajaran peminatan. Bagi siswa dengan peminatan utama Ilmu-Ilmu Sosial (IIS), mata pelajaran Sejarah kelas $\mathrm{X}$ mendorong siswa untuk mampu memahami dan menerapkan langkah-langkah 
penelitian sejarah dalam mempelajari sumber sejarah yang ada di sekitarnya. Secara lebih luas, mata pelajaran Sosiologi juga mendorong siswa untuk memahami metode penelitian sosial sederhana dan mampu melakukan penelitian sosial sederhana untuk mengenali gejala sosial di masyarakat serta menemukan pemecahan masalah sosial dan konflik di masyarakat. Bagi siswa dengan peminatan Bahasa, salah satu kompetensi dasar di kelas XI adalah menyusun karya tulis ilmiah yang sesuai dengan konvensi penulisan karya tulis ilmiah. Pada mata pelajaran Antropologi, siswa SMA peminatan Bahasa juga harus mampu menyusun rancangan, melaksanakan, dan mengkomunikasikan hasil penelitian sederhana terkait dengan budaya setempat, budaya nasional, hubungan antar budaya, kecenderungan pelemahan nilai-nilai budaya tradisional, perubahan sosial budaya, perkembangan ilmu pengetahuan dan teknologi (IPTEK), serta globalisasi. Bagi siswa dengan peminatan utama Matematika dan Ilmu Pengetahuan Alam (MIPA), hampir semua mata pelajaran sains mendorong siswa untuk mampu melakukan kerja ilmiah dan melaporkan hasilnya secara ilmiah pula.

Pengembangan kemampuan siswa dalam menyusun karya ilmiah maupun laporan penelitian sederhana tentu harus didukung dengan kemampuan untuk memilih sumber-sumber informasi yang valid guna mendukung tulisannya itu. Mengingat tidak sedikit siswa yang telah dapat mengakses internet, sudah selayaknya dilakukan penelitian guna mengungkap sejauh mana kemampuan siswa dalam memanfaatkan sumber informasi di internet. Kemampuan dalam memanfaatkan informasi merupakan modal penting guna menyusun karya tulis ilmiah atau laporan penelitian yang bermutu.
Penelitian ini bertujuan untuk mendeskripsikan penggunaan sumber-sumber informasi di internet dalam penyusunan karya tulis ilmiah oleh siswa Sekolah Menengah Atas (SMA). Secara umum, sumber-sumber informasi yang digunakan sebagai dasar suatu ide atau gagasan dalam karya tulis ilmiah akan didaftar pada bagian akhir karya tulis ilmiah, yang dikenal sebagai daftar pustaka. Analisis daftar pustaka inilah yang dikenal sebagai analisis sitiran (citation analysis). Mengacu pada Junandi (2015), analisis sitiran digunakan untuk mengukur pengaruh intelektual keilmuan dari pengarang yang disitir serta untuk mengetahui karakteristik komunikasi ilmu pengetahuan dan aspek kualitatif dari publikasi ilmiah. Analisis ini umum digunakan untuk menguji keman-faatan perpustakaan, misalnya dalam Anggraini \& Nst (2013) dan Arif (2017). Dalam konteks penggunaan sumber internet, analisis sitiran telah banyak digunakan misalnya oleh Cooke and Rosenthal (2011), Hendley (2012) dan Howard, Nicholas, Hayes, \& Appelt (2014), yang sebagian besar analisis sitiran digunakan untuk karya-karya tulis mahasiswa.

Selain itu, dalam penelitian Junandi (2018), mengenai penggunaan jurnal ilmiah pun menggunakan analisis sitiran sebagai teori untuk menganalisisnya. Hasilnya dari informasi jurnal ilmiah Agritech tersebut, terlihat aktivitas penggunaannya sebagai rujukan jurnal ilmiah terindeks Scopus.

Bagi para guru, informasi mengenai penggunaan internet sebagai sumber informasi oleh siswa SMA dapat menjadi salah satu acuan guna mengukur kemampuan siswa untuk mencari dan menemukan informasi yang akurat dengan efektif dan efisien. Kemampuan tersebut menjadi 
salah satu kunci agar siswa mampu melakukan penelitian sederhana sesuai dengan kompetensi dasar pada beberapa mata pelajaran yang telah dikemukakan di atas. Bila kemampuan tersebut dirasa masih rendah, guru bersama-sama dengan pustakawan sekolah dapat merancang berbagai program untuk meningkatkan kemampuan siswa tersebut.

\section{METODE PENELITIAN}

Penelitian ini dilakukan pada bulan Juni 2018 sampai dengan Agustus 2018 di Perpustakaan SMA Negeri 8 Yogyakarta, Jalan Sidobali 1 Muja-Muju Umbulharjo Yogyakarta 55165.

Penelitian ini menggunakan metode kuantitatif dengan pendekatan deskriptif. Mengacu pada Sugiyono (2013), “Metode kuantitatif dilandasi oleh filsafat positivisme, digunakan untuk menganalisis data populasi berdasarkan data sampel dan menggunakan teknik-teknik statistik untuk menarik kesimpulan. Penelitian ini juga menggunakan pendekatan deskriptif".

Selain itu, penelitian ini menggunakan kajian bibliometrik. Rohanda (2013) menyatakan bahwa kajian ini merupakan, "Contoh-contoh artikel yang disitir. Artikel dimaksud adalah artikel yang ada pada jurnal ilmiah yang ditulis oleh para ilmuwan dari hasil kajian dan penelitian-penelitian yang ia lakukan baik merupakan pengkajian tentang teori atau penemuanpenemuan teori-teori baru. Kemudian hasil kajian itu disitir, dikutip ilmuwan lain. Setiap ilmuan dalam melakukan kajiannya itu menyitir karya-karya ilmuwan lain yang telah dilakukan lebih dahulu".

Dalam penelitian ini, kami menganalisis karya tulis ilmiah dari seluruh karya tulis ilmiah siswa-siswi, dalam bentuk laporan penelitian yang disusun oleh siswa kelas $X$ Sekolah Menengah Atas (SMA) Negeri 8 Yogyakarta pada tahun ajaran 2016/2017 dan tahun ajaran 2017/2018. Bahan-bahan berupa laporan penelitian tersebut dikumpulkan dari seluruh siswa pada saat Penilaian Akhir Tahun Ajaran (PAT). Seluruh daftar pustaka pada makalahmakalah tersebut dikelompokkan sesuai dengan jenis atau bentuknya, bahasa yang digunakan, serta tahun penerbitannya. Pencatatan hasil penggolongan dilakukan dengan bantuan perangkat lunak microsoft excel. Hasil pencatatan kemudian diolah dan disajikan dalam bentuk tabel-tabel maupun diagram yang sesuai.

\section{HASIL DAN PEMBAHASAN}

Dari tahap pengumpulan data, diperoleh 166 laporan penelitian yang memiliki daftar pustaka atau bibliografi. Setiap laporan disusun secara bersama-sama oleh kelompok yang terdiri dari dua atau tiga orang siswa.

Laporan-laporan penelitian tersebut dapat dikelompokkan berdasarkan bidang ilmunya menjadi tiga kelompok, yakni bidang Ilmu Sosial dan Humaniora, bidang Sains Hayati - Kesehatan - Pangan, serta bidang Sains Rekayasa - Teknik Komputer. Sebaran bidang penelitian siswa tersebut dapat dilihat pada gambar 1 berikut.

Dari gambar 1., terlihat bahwa karya tulis siswa didominasi oleh bidang Sains Hayati, Kesehatan, dan Pangan serta bidang Ilmu Sosial dan Humaniora. Bidang-bidang ini sengaja tidak dipisahkan lebih lanjut menjadi sejumlah sub bidang, mengingat penelitian siswa SMA tidak jarang bersifat multidisiplin, saling terkait, 
dan sulit dibedakan antara satu bidang dengan bidang lainnya.

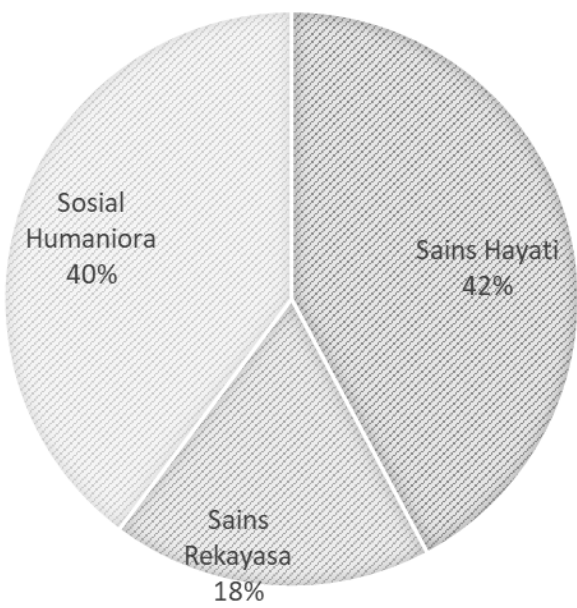

Gambar 1. Sebaran Bidang Laporan Penelitian Siswa

Sumber: Hasil penelitian, 2018

Sebaran jumlah sumber referensi yang digunakan pada masing-masing la-poran penelitian siswa dapat dilihat pada gambar 2 . berikut.

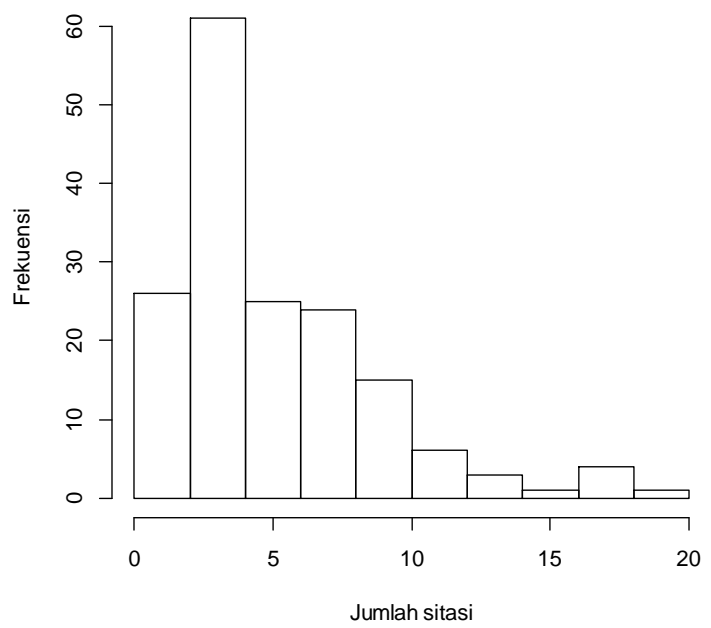

Gambar 2. Sebaran jumlah sitasi dalam karya tulis siswa

Sumber: Hasil penelitian, 2018

Dari gambar 2. di atas, terlihat bahwa sebagian besar laporan penelitian dibuat berdasarkan tidak lebih dari 10 referensi. Adapun jumlah referensi maksimum yang digunakan dalam laporan penelitian siswa adalah sebanyak 18 buah (1 laporan). Adanya variasi jumlah referensi yang digunakan ini tidak lepas dari belum adanya ketentuan mengenai jumlah referensi minimum dan maksimum yang digunakan dalam penulisan karya ilmiah oleh siswa SMA. Di sisi lain, meskipun akses ke situs-situs jurnal dan situs repositori hasil penelitian dapat dilakukan, tidak semua siswa SMA dapat memahami isi jurnal atau laporan penelitian tersebut.

Tabel 1.

Sebaran referensi laporan penelitian bidang sains hayati

\begin{tabular}{lll}
\hline Sumber & Jumlah & Persentase \\
\hline Buku & 46 & $11,04 \%$ \\
Berkala Cetakan & 3 & $0,75 \%$ \\
Internet & 256 & $63,68 \%$ \\
Lainnya & 97 & $24,13 \%$ \\
\hline Total & 402 & $100 \%$
\end{tabular}

Sumber: Hasil penelitian, 2018

Tabel 2

Sebaran referensi laporan penelitian bidang sains teknik - rekayasa - dan komputer

\begin{tabular}{lll}
\hline Sumber & Jumlah & Persentase \\
\hline Buku & 17 & $9,66 \%$ \\
Berkala Cetakan & 1 & $0,57 \%$ \\
Internet & 115 & $65,34 \%$ \\
Lainnya & 43 & $24,43 \%$ \\
\hline Total & 176 & $100 \%$ \\
\hline
\end{tabular}

Sumber: Hasil penelitian, 2018

Tabel 3

Sebaran referensi laporan penelitian bidang ilmu sosial dan humaniora

\begin{tabular}{lll}
\hline Sumber & Jumlah & Persentase \\
\hline Buku & 51 & $15,09 \%$ \\
Berkala Cetakan & 1 & $0,29 \%$ \\
Internet & 206 & $60,95 \%$ \\
Lainnya & 80 & $23,67 \%$ \\
\hline Total & 338 & $100 \%$ \\
\hline
\end{tabular}

Sumber: Hasil penelitian, 2018

Selanjutnya akan ditinjau referensireferensi yang digunakan oleh siswa pada masing-masing bidang penelitian. Mengacu pada tabel 1, tabel 2, dan tabel 3 di atas, terlihat bahwa sebagian besar 
sumber informasi atau referensi yang digunakan dalam penelitian siswa adalah sumber internet. Apabila data tersebut ditambah dengan sumber-sumber internet yang digolongkan pada kelompok lainlain (misal jurnal online atau skripsi yang diambil dari situs repositori), maka lebih dari $75 \%$ referensi dalam laporan siswa diambil dari internet. Hasil ini menunjukkan bahwa internet banyak digunakan dalam penyusunan laporan penelitian.

Rendahnya penggunaan buku-buku dalam penulisan karya ilmiah oleh siswa SMA dapat dijelaskan sebagai berikut. Pertama, gagasan penelitian siswa SMA tidak jarang muncul dari keperluan praktis sehari-hari sehingga tidak mudah mencari buku yang mendukung gagasan tersebut. Kedua, koleksi perpustakaan sekolah lebih banyak didominasi oleh buku-buku pelajaran dan penunjang pelajaran. Bukubuku referensi yang tersedia bersifat umum (misalnya ensiklopedia). Jarang dijumpai buku-buku referensi yang bersifat spesifik pada bidang tertentu. Di samping itu, belum semua siswa tertarik melakukan pencarian ke perpustakaanperpustakaan lain, misalnya perpustakaan daerah atau perpustakaan perguruan tinggi terdekat.

Untuk menganalisis sumber-sumber internet, mula-mula dilakukan identifikasi dan pengkategorian situs internet. Berdasarkan jenis lembaga pemilik situs serta bentuk situs, peneliti membuat klasifikasi situs internet menjadi 11 kelompok yakni, (1) situs pers, (2) situs lembaga negara, (3) situs repositori, (4) situs organisasi non pemerintah, (5) situs jurnal ilmiah, (6) situs kumpulan dokumen, (7) situs pribadi, (8) situs Wikipedia, (9) situs jasa, (10) situs jual-beli, dan (11) situs "umum" atau lainlain.
Situs pers atau surat kabar elektronik (e-newspaper) dikelola oleh organisasi atau lembaga yang telah diverifikasi oleh dewan pers. Daftar situs surat kabar elektronik yang telah terverifikasi dapat dilihat pada http://dewanpers.or.id. Situs penyedia berita yang tidak terverifikasi oleh dewan pers tidak dapat disebut sebagai surat kabar elektronik. Pengumpulan informasi-informasi untuk dimuat dalam situs surat kabar elektronik umumnya dilakukan oleh para wartawan yang terikat oleh peraturan atau kode etik wartawan. Situs-situs pers ini pada umumnya memperoleh informasi dari sumber primer.

Kelompook situs lembaga menunjuk pada situs milik lembaga negara. Secara umum, Kamus Besar Bahasa Indonesia (KBBI) menyebutkan, "Lembaga sebagai badan atau organisasi yang tugasnya melakukan suatu penyelidikan keilmuan atau melakukan suatu usaha" (Kementrian Pendidikan dan Kebudayaan, 2016). Dalam penelitian ini, lembaga didefinisikan sebagai suatu badan yang dikelola oleh pemerintah, meliputi lembaga tinggi negara, lembaga kejaksaan, pengadilan, Tentara Nasional Indonesia (TNI), Kepolisian Republik Indonesia, instansi kedinasan, sekolah, perguruan tinggi, dan sebaginya. Situs-situs ini umumnya menggunakan alamat berakhiran go.id, ac.id, dan mil.id. Isi situssitus ini menjadi tanggung jawab lembaga pemilik situs sepenuhnya.

Situs repositori perguruan tinggi dan lembaga penelitian, umumnya memuat laporan penelitian lengkap dan/atau naskah publikasi, baik berasal dari tugas akhir mahasiswa maupun proyek-proyek tertentu. Beberapa contoh situs repositori antara lain repository.ugm.ac.id milik Universitas Gadjah Mada (UGM), rdip.lipi.go.id 
yang dikelola oleh Lembaga Ilmu Pengetahuan Indonesia (LIPI), dan sebagainya. Universitas-universitas besar umumnya memiliki situs repositori semacam ini.

Situs resmi badan atau organisasi non pemerintah meliputi situs lembaga profit dan non profit milik swasta maupun lembaga-lembaga swadaya masyarakat (LSM). Termasuk dalam kategori ini adalah lembaga-lembaga bimbingan belajar, organisasi atau kelompok masyarakat, partai politik, berbagai macam perusahaan, dan sebagainya.

Berdasarkan Kamus Besar Bahasa Indonesia (KBBI), jurnal didefinisikan sebagai, "Majalah yang memuat informasi mengenai suatu topik ilmiah tertentu. Jurnal ilmiah diterbitkan oleh perguruan tinggi, asosiasi profesi, atau oleh lembaga penerbit tertentu" (Kementrian Pendidikan dan Kebudayaan, 2016). Pada umumnya artikel atau makalah pada jurnal ilmiah telah melalui proses penilaian (review) oleh para ahli di bidangnya. Suatu situs jurnal ilmiah umumnya juga memiliki nomor seri standar internasional (international standard serial number, ISSN).

Kelompok situs kumpulan dokumen umumnya digunakan untuk menyimpan berbagai dokumen. Situs-situs dalam kelompok ini meliputi google drive (drive.google.com), dropbox (www.dropbox. com), slide share (slideshare. net), scribd (www.scribd.com), 4shared (4shared.com), dan lain sebagainya. Pengguna situs ini dapat mengunggah berbagai macam dokumen tanpa verifikasi sehingga tidak dapat dipastikan apakah orang yang mengunggah dokumen ke situs-situs tersebut juga merupakan penulis yang bertanggung jawab terhadap isi dokumen. Tidak jarang pula dokumen yang diunggah berasal dari sumber lain.
Situs web pribadi dikelola secara pribadi oleh perorangan dan umumnya berupa media sosial, meliputi situs blog, akun facebook, friendster, twitter, instagram, akun academia.edu, dan lain sebagainya. Mengacu pada Wijaya, Suhartono dan Sutopo (2016) media sosial merupakan adalah alat berbasis komputer yang memungkinkan orang untuk membuat, berbagi, atau bertukar informasi, ide, gambar atau video dalam komunitas dan jaringan virtual, adapun informasi di media sosial tidak semuanya benar.

Situs wikipedia merupakan sebuah ensiklopedia daring besar yang tersedia dalam berbagai bahasa. Situs ini menyediakan informasi yang lengkap dan mudah dipahami. Di sisi lain, situs ini memiliki kelemahan besar yakni setiap orang bisa mengakses dan menambahkan atau memanipulasi informasi yang tersedia pada situs ensiklopedia ini sehingga informasi yang tersedia pada situs ini tidak selalu benar.

Situs jasa merupakan situs-situs penyedia berbagai macam jasa, yang umumnya dikelola oleh ahli-ahli di bidangnya. Sebagai contoh, terdapat situs alodokter.com dan klikdokter.id yang dikelola oleh para dokter dan situs hukumonline.com yang dikelola oleh para pakar hukum.

Situs jual beli merupakan kelompok situs internet yang sengaja dirancang untuk keperluan jual beli barang dan jasa, baik secara langsung (sebagai penyedia barang atau jasa) maupun secara tidak langsung (sebagai perantara). Beberapa contoh situs jual beli antara lain tokopedia.com dan bukalapak. com (sebagai perantara), olx.com (hanya memuat iklan), shopee.com dan zalora.com (penyedia barang), dan lain lain.

Kelompok situs umum mencakup situs-situs internet yang tidak dapat digo- 
longkan pada salah satu dari ke-10 macam situs internet di atas. Sebagai contoh situs kaskus.com, situs quora.com, ruangguru.com, stackoverflow.com dan situs-situs diskusi lainnya. Informasi yang tersedia pada situs ini dapat berasal dari sembarang pengguna internet. Situs-situs yang menyediakan informasi umum (bukan dari ahli) juga dimasukkan pada kelompok ini.

Dalam klasifikasi tersebut, masih ada beberapa kendala yang perlu menjadi perhatian yakni sebagai berikut.

Pertama, identifikasi situs berita umumnya tidak mudah. Tidak jarang dijumpai situs berisi informasi dengan "gaya" berita, padahal situs tersebut hanya mengolah informasi dari berbagai situs lain dan tidak melakukan pengumpulan informasi sendiri. Tidak jarang dijumpai informasi dengan judul yang bombastis, atau informasi tanpa sumber yang jelas (tanpa identitas informan, tanggal wawancara, dan sebagainya). Situs semacam ini tidak dapat dimasukkan sebagai situs berita. Situs opini yang tersedia untuk menampung pendapat bebas dari berbagai pihak yang menjadi anggotanya, misalnya kompasiana.com, seword.com dan lain sebagainya walaupun kadangkala diisi dengan informasi faktual, juga tidak dapat digolongkan sebagai situs berita. Situs-situs opini harus diperlakukan seperti situs pribadi.

Situs lembaga resmi juga harus dibedakan dengan situs pribadi yang berasosiasi dengan lembaga itu. Beberapa lembaga pendidikan menyediakan platform untuk situs pribadi masing-masing orang dengan alamat yang memuat nama lembaga. Sebagai contoh, Universitas Gadjah Mada (UGM) menyediakan situs pribadi untuk para dosennya dengan alamat yang diikuti http://staff.ugm.ac.id/.
Walaupun berakhiran ac.id, situs-situs semacam ini tetap harus dipandang sebagai situs pribadi, bukan situs resmi lembaga.

Kedua, tidak jarang situs-situs yang seolah menyediakan informasi "umum" ternyata merupakan situs jual beli, sehingga kebenaran informasi di dalamnya tidak selalu tepat. Sebagai contoh, informasi tentang manfaat suatu obat dari suatu situs bisa saja hanya merupakan klaim penjual untuk menarik calon pembeli.

Dewasa ini, lembaga-lembaga ne-gara, universitas, maupun perusahaan swasta seringkali juga memiliki akun media sosial, baik berupa akun atau hala-man facebook, twitter, bahkan instagram. Sejauh akun media sosial tersebut meru-pakan akun resmi yang telah diverifikasi, informasi yang tersedia pada akun tersebut dapat dianggap senilai dengan informasi pada situs resmi. Dalam hal ini, pengguna harus membedakan akun resmi dengan halaman penggemar (fanpage) atau bahkan akun-akun palsu.

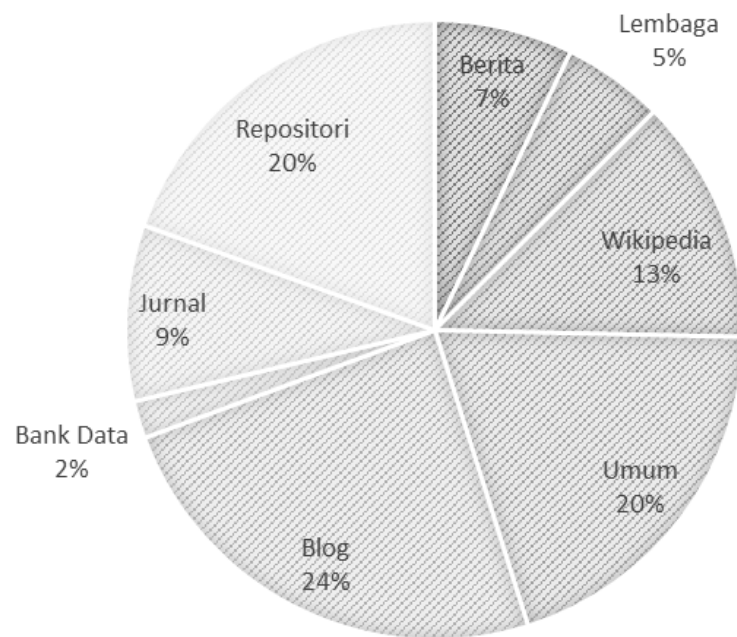

Gambar 3. Sebaran referensi internet untuk laporan penelitian bidang sains hayati Sumber: Hasil penelitian, 2018 


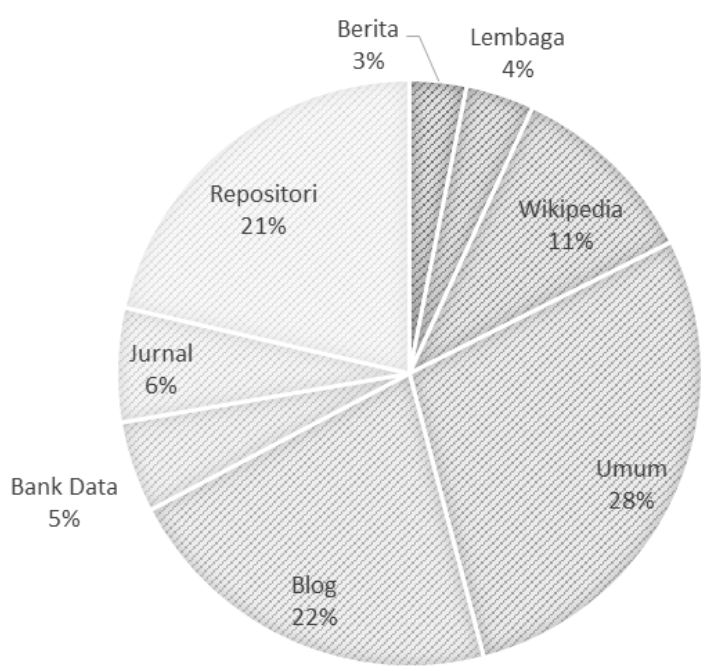

Gambar 4. Sebaran referensi internet untuk laporan penelitian bidang rekayasa dan teknik Sumber: Hasil penelitian, 2018

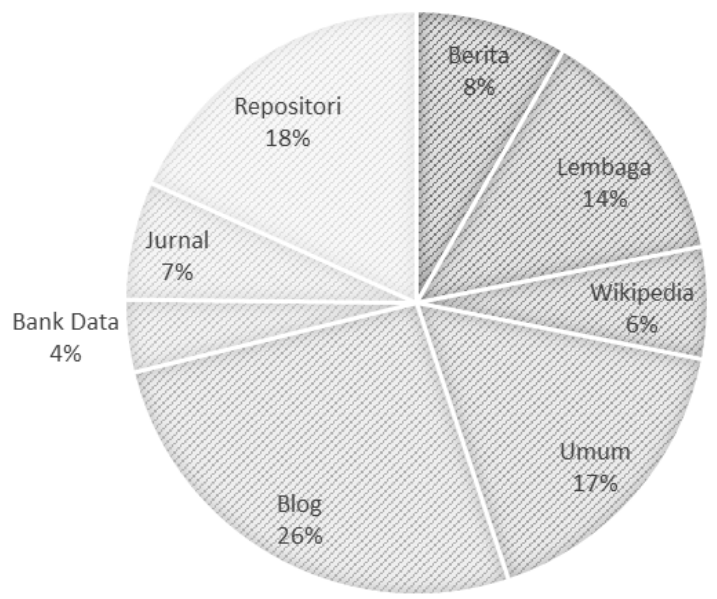

Gambar 5. Sebaran referensi internet untuk laporan penelitian bidang sosial-humaniora

Sumber: Hasil penelitian, 2018

Gambar 3. hingga gambar 5. di samping menunjukkan penggunaan berbagai sumber dari internet dalam penulisan karya tulis ilmiah oleh siswasiswi SMA pada tiga bidang penelitian.

Dari gambar-gambar tersebut, terlihat bahwa situs karya ilmiah (jurnal dan repositori) menyusun sekitar 25\% dari total referensi. Jumlah kutipan dari kedua kelompok situs ini lebih kecil dari total kutipan dari situs blog dan Wikipedia. Kelompok situs lembaga dan situs berita hanya dikutip kurang dari $20 \%$ penelitian. Dalam pengelompokan ini, blog juga mencakup situs media sosial pribadi (akun facebook, twitter, dan sebagainya). Pada ketiga bidang, referensi internet berupa jurnal hanya menyusun kurang dari 10\% referensi, lebih sedikit dibandingkan sumber informasi dari situs repositori.

Dengan membandingkan bidang-bidang penelitian, terlihat bahwa riset bidang Sosial Humaniora lebih banyak menggunakan situs-situs lembaga dan sedikit menggunakan situs Wikipedia. Sebaliknya, bidang Riset Sains Hayati paling banyak menggunakan sumber atau referensi berupa jurnal ilmiah dibanding bidang-bidang riset lainnya. Situs repositori yang memuat hasil-hasil penelitian paling banyak digunakan pada riset-riset bidang teknik dan rekayasa.

Tingginya penggunaan situs blog dan Wikipedia dibandingkan situs-situs lembaga, berita, dan hasil penelitian (jurnal dan repositori) menunjukkan bahwa siswa cenderung mengambil sembarang informasi di internet dan belum mempertimbangkan ketepatan atau validitas informasi yang tersedia. Hal ini dapat disebabkan oleh kurangnya diskusi maupun paparan terkait dengan validitas informasi kepada para pelajar SMA.

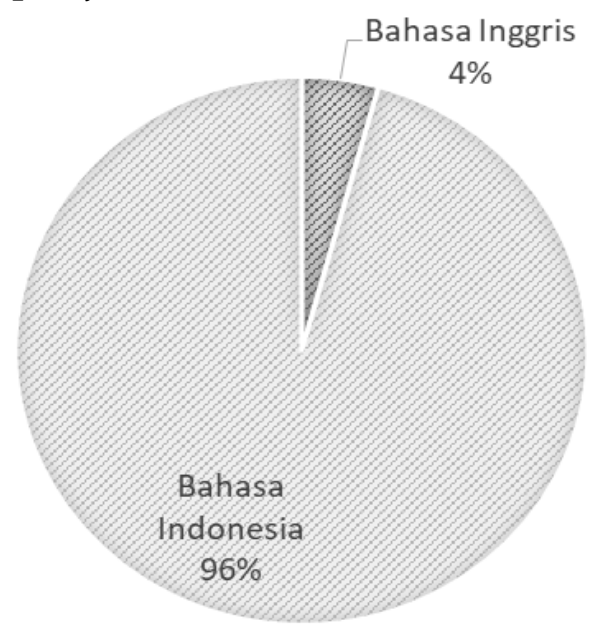

Gambar 6. Sebaran bahasa yang digunakan pada Referensi Internet dalam penelitian siswa SMA Sumber: Hasil penelitian, 2018

Dengan melakukan pengecekan terhadap situs-situs berdomain luar negeri 
dan alamat situs non berbahasa Indonesia, dapat diperoleh data sebaran bahasa sebagaimana ditunjukkan pada gambar 6 . Terlihat bahwa hanya $4 \%$ referensi yang diambil dari situs berbahasa Inggris sedangkan sisanya diambil dari situs berbahasa Indonesia.

Tantangan lain dalam analisis sitasi pada karya tulis siswa Sekolah Menengah Atas (SMA) berkaitan erat dengan penulisan daftar pustaka atau bibliografi. Materi penulisan berbagai jenis sumber dalam daftar pustaka umumnya belum diberikan di jenjang SMA. Akibatnya, tidak jarang dijumpai ketidakjelasan jenis referensi pada daftar pustaka laporan penelitian siswa SMA. Kendala lain terkait jumlah sitasi yang sangat rendah (lihat gambar 2. di muka) menunjukkan bahwa penyusunan daftar pustaka belum menjadi perhatian dalam penulisan karya tulis ilmiah oleh siswa-siswi SMA. Kedua hal ini yang menjadi kendala analisis sitasi pada karya tulis siswa SMA, bila dibandingkan dengan analisis sitasi pada karya tulis mahasiswa.

\section{SIMPULAN}

Dari penelitian ini diketahui bahwa internet merupakan sumber utama yang digunakan siswa SMA dalam menyusun karya tulis ilmiah. Dalam menggunakan internet, sebagian besar siswa SMA belum banyak mengambil sumber-sumber berupa jurnal, situs lembaga resmi, atau repositori bila dibandingkan dengan sumber berupa blog, Wikipedia, atau si-tussitus umum lainnya. Dari segi bahasa, sebagian besar situs yang digunakan sebagai sumber informasi adalah situs berbahasa Indonesia.

Penelitian lebih lanjut dapat dilakukan untuk memperdalam faktor-faktor yang mempengaruhi pemilihan sumber informasi pada siswa SMA dan mengumpulkan informasi yang lebih jelas terkait referensi penelitian siswa SMA dengan sampel yang lebih besar. Penelitian ini juga dapat dilakukan untuk mengetahui pemakaian sumber informasi pada subjek lain, misalnya siswa SMK/MA.

\section{DAFTAR PUSTAKA}

Anggraini, L., \& Nst, B. (2013). Evaluasi ketersediaan koleksi dengan menggunakan analisis sitiran terhadap tesis Mahasiswa Pascasarjana Pro-gram Studi Ilmu Biomedik Tahun 2012 di Perpustakaan Fakultas Kedokteran Universitas Andalas. Jurnal Ilmu Informasi Perpustakaan Dan Kearsipan, 2(1), 159-168. https://doi.org/https:/ / doi.org/10.2 4036/2319-0934

APJII. (2017). Hasil survey penetrasi dan perilaku pengguna internet Indonesia 2017. Retrieved from https:/ /apjii.or.id/ surve

Arif, I. (2017). Pemanfaatan koleksi Perpustakaan Fakultas Hukum Universitas Gadjah Mada untuk karya akhir mahasiswa: Kajian analisis sitasi. Berkala Ilmu Perpustakaan Dan Informasi, 13(2), 155-165. https://doi.org/https://doi.org/10.2 2146/bip. 27494

Cooke, R., \& Rosenthal, D. (2011). Students use more books after library instruction: An analysis of under graduate paper citations. College and Research Libraries, 72(4), 332-343. Retrieved from https://crl.acrl.org/index.php/crl/ar ticle/viewFile/16166/17612

Handayani, R. I. (2012). Tata Kelola Teknologi Indormasi Pada Smk Averus Menggunakan Framework 
Control Objectives for Information and Related Technology (Cobit) Versi 4.0. Jurnal Pilar Nusa Mandiri,8(2), 142-148.

Hendley, M. (2012). Citation behavior of undergraduate students: A study of history, political science, and sociology papers. Behavioral \& Social Sciences Librarian, 31(2), 96-111. https:/ / doi.org/http:/ /dx.doi.org/10 $.1080 / 01639269.2012 .679884$

Howard, K., Nicholas, T., Hayes, T., \& Appelt, C. W. (2014). Evaluating oneshot library sessions: Impact on the quality and diversity of student source use. Community $\mathcal{E}$ Junior College Libraries, 20(1-2), 27-38. https:/ / doi.org/https:/ / doi.org/10.1 080/02763915.2014.1009749

Imron, M. S., Palekahelu, D. T., \& Somya, R. (2014). Perancangan dan implementasi aplikasi pembelajaran siklus camot berbasis rich internet application untuk pelajar SMA: Studi kasus SMA Negeri 3 Salatiga. Jurnal Teknologi Informasi, 11(1), 61-76.

Joo, S., \& Choi, N. (2015). Factors affecting undergraduates' selection of online library resources in academic tasks: Usefulness, ease-of-use, resour-ce quality, and individual differences. Library Hi Tech, 33(2), 272-291. https:/ / doi.org/https:/ / doi.org/10.1 108/LHT-01-2015-0008

Junandi, S. (2015). Analisis Sitiran Karya Ilmiah Pustakawan Indonesia pada Jurnal Visi Pustaka Tahun 2008-2013. Ilmu Perpustakaan dan Informasi, 11(1), 44-53.

Junandi, S. (2018). Keterpakaian dan relevansi Jurnal Agritech sebagai rujukan artikel jurnal ilmiah internasional terindeks Scopus. Kajian Informasi E Perpustakaan, 6(1), 95-108.
Retrieved from http://jurnal.unpad.ac.id/jkip/article /view/15066/8256

Kementrian Pendidikan dan Kebudayaan. (2016). KBBI daring. Retrieved from https://kbbi.kemdikbud.go.id/entri/ terbuka

Kim, K.-S., \& Sin, S.-C. J. (2011). Selecting quality sources: Bridging the gap between the perception and use of information sources. Journal of Information Science, 37(2), 178-188. https://doi.org/https:/ / doi.org/10.1 177\%2F0165551511400958

Lestari, S. (2015). Pengaruh kualitas informasi, kemampuan individual, dan norma subyektif terhadap minat mahasiswa dalam menggunakan internet sebagai sumber pustaka dalam penyelesaian tugas-tugas kuliah (Survey di Universitas Muhammadiyah Surakarta) (Skripsi). Universitas Muhammadiyah, Surakarta. Retrieved from http:/ / onesearch.id/Record/IOS2728 .39030

Prasetiadi, A. E. (2011). Web 3.0: Teknologi masa depan. Jurnal Indept, 1(3), 1-6. Retrieved from http://jurnal.unnur.ac.id/index.php/ indept/article/view/78/51

Purdy, J. P. (2012). Why first-year college students select online research resources as their favorite. Journal First Monday, 17(9-3), 1-10. Retrieved from

https:/ / firstmonday.org/article/vie w/4088/3289

Rahardiyan K., E. (2014). Pemanfaatan internet dan dampaknya pada pelajar sekolah menengah atas di Surabaya. Libri-Net, 3(1), 407 - 420.

Rohanda. (2013). Landasan ilmiah ilmu informasi perpustakaan dalam perspektif ilmu komunikasi. Kajian 
Informasi $\mathcal{E}$ Perpustakaan, 1(1), 9-20.

Retrieved

from

http://jurnal.unpad.ac.id/jkip/article /view/9592/4316

Selwyn, N. (2008). An investigation of differences in undergraduates' academic use of the internet. Active Learning in Higher Education, 9(1), 1122.

https://doi.org/https://doi.org/10.1 177\%2F1469787407086744

Sin, S-C. J., \& Kim, K.-S. (2013). International students' everyday life information seeking: The information value of social networking sites. Library and Information Science Research, 35(2), 107-116. https:/ / doi.org/https:/ / doi.org/10.1 016/j.lisr.2012.11.006

Suara Sektor ICT Indonesia. (2017). MASTEL: Masyarakat sudah kritis tanggapi berita hoax. Retrieved from https://mastel.id/mastelmasyarakat-sudah-kritis-tanggapiberita-hoax/

Sugiyono. (2013). Metode Penelitian Kuantitatif, Kualitatif dan RED. Bandung: Alfabeta.

Suharni, S. (2012). Pengaruh kualitas informasi, kemampuan individual dan norma subyektif terhadap minat mahasiswa dalam menggunakan internet sebagai sumber pustaka (Survey di Universitas Muhammadiyah Surakarta) (Skripsi). Universitas Muhammadiyah Surakarta.

Supardi, K. I., Putri, I. R. (2010). Pengaruh penggunaan artikel kimia dari internet pada model pembelajaran creative problem solving terhadap hasil belajar Siswa SMA. Jurnal Inovasi
Pendidikan Kimia, 4(1), 574-581.

Retrieved from https://journal.unnes.ac.id/nju/inde x.php/JIPK/article/view/1315/1392

Wardhani, R. A. S. K. (2013). Hubungan pemanfaatan internet sebagai sumber belajar dan minat belajar dengan prestasi belajar sosiologi Siswa kelas XI Ilmu Pengetahuan Sosial SMA Negeri 4 Surakarta tahun Ajaran 2012/2013. SOSIALITAS: Jurnal Ilmiah Pendidikan Sosiologi-Antropologi, 3(1), 1-11. Retrieved from http://jurnal.fkip.uns.ac.id/index.ph $\mathrm{p} /$ sosant/article/view/2273/1651

Wijaya, D. M., Suhartono, A. W. dan Sutopo, A. R. (2016). Perancangan iklan layanan masyarakat untuk orang berusia 18-25 tahun agar kritis dalam menerim informasi di media sosial. Jurnal DKV Adiwarna, 1(8), 1-9.

Yale University. (2018). Citing internet sources. Retrieved from https://poorvucenter.yale.edu/writi ng/using-sources/citing-internetsources

Zahra, F. (2009). Pengaruh kualitas informasi, kemampuan individual dan norma subyektif terhadap niat mahasiswa dalam menggunakan internet sebagai sumber pustaka (Tesis). Universitas Gadjah Mada, Yogyakarta. Retrieved from http://etd.repository.ugm.ac.id/inde x.php?mod=penelitian_detail\&sub=P enelitianDetail\&act=view\&typ $=\mathrm{html}$ \&buku_id=42642 